\title{
Managing nursing care delivery to cancer patients in a general hospital: a Grounded Theory
}

\author{
Gestão do cuidado de enfermagem ao paciente oncológico num hospital geral: \\ uma Teoria Fundamentada nos Dados \\ Gestión del cuidado de enfermería a pacientes con cáncer en un hospital general: \\ una Teoría Fundamentada en los Dados \\ Caroline Cechinel Peiter*; Maria Eduarda Pereira Caminha**; Gabriela Marcellino de Melo Lanzoni***; \\ Alacoque Lorenzini Erdmann****
}

\begin{abstract}
Background: Cancer incidence rates have been increasing, and today cancer is the second most fatal non-communicable disease in the world.

Objectives: To understand the meaning of the management of nursing care delivery to cancer inpatients in a general hospital.

Methodology: This qualitative research used the Grounded Theory methodology. Semi-structured interviews were performed with 14 participants (6 nurses, 5 nursing technicians, 1 nutritionist, 1 psychologist, and 1 patient's relative) between August and October 2010.

Results: After analysis, 13 categories emerged. The core category was Understanding how professionals excel themselves and how important is interdisciplinarity when comparing the management of humanistic and humanitarian nursing care recommended for cancer patients with the health professionals and family members' experiences in an inpatient unit of a general hospital.

Conclusion: The management of nursing care delivery to cancer patients is considered to be strategic to patient-centered care. Both patients and family perceive nursing as their main source of support. Multidisciplinary care and ongoing training are identified as promoters of cancer patient care.
\end{abstract}

Keywords: oncologic nursing; medical oncology; disease management; grounded theory

\section{Resumo}

\begin{abstract}
Enquadramento: Verifica-se o crescente aumento na incidência de cancro, sendo atualmente a segunda doença não transmissível que mais mata no mundo.

Objetivos: Compreender o significado da gestão do cuidado de enfermagem aos pacientes oncológicos internados num hospital geral. Metodologia: Pesquisa qualitativa. Utilizou-se a Teoria Fundamentada nos Dados. Realização de entrevistas semiestruturadas a 14 sujeitos (6 enfermeiros, 5 técnicos de enfermagem, 1 nutricionista, 1 psicóloga e 1 familiar) de agosto a outubro de 2010.

Resultados: Após análise alcançaram-se 13 categorias, revelando-se a categoria central Perceber a superação do profissional e a importância da interdisciplinaridade ao contrastar a gestão do cuidado de enfermagem humanístico e humanitário preconizado ao paciente oncológico com o vivenciado pelos profissionais de saúde e familiares, numa unidade de internamento hospitalar geral.

Conclusão: A gestão do cuidado de enfermagem ao paciente oncológico é considerada estratégia para efetivação de um cuidado direcionado. A enfermagem é percebida como o principal apoio do paciente e família. O cuidado multiprofissional e capacitação permanente são identificados como potencializadores do cuidado ao paciente oncológico.
\end{abstract}

Palavras-chave: enfermagem oncológica; oncologia; gerenciamento clínico; teoria fundamentada nos dados

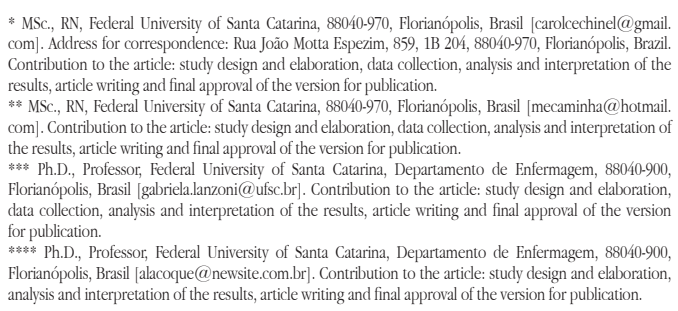

\section{Resumen}

Marco contextual: Existe un creciente aumento en la incidencia de cáncer, actualmente la segunda enfermedad no contagiosa que más muertes produce.

Objetivos: Comprender el significado de la gestión de los cuidados de enfermería a pacientes con cáncer en un hospital general.

Metodología: Investigación cualitativa en la que se utilizó la Teoría Fundamentada en los Datos. Para ello se realizaron entrevistas semiestructuradas con 14 sujetos (6 enfermeros, 5 técnicos de enfermería, 1 nutricionista, 1 psicóloga y 1 familiar), de agosto hasta octubre de 2010.

Resultados: Después del análisis se obtuvieron 13 categorías, entre ellas la categoría central Comprender la superación del profesional y la importancia de la interdisciplinariedad al contrastar la gestión de los cuidados de enfermería humanísticos y humanitarios recomendados para pacientes con cáncer con las experiencias de los profesionales de la salud y los familiares en una unidad hospitalaria general.

Conclusión: La gestión de los cuidados de enfermería a pacientes con cáncer se considera una estrategia de ejecución de una atención dirigida. La enfermería se entiende como el apoyo principal del paciente y su familia. La atención multidisciplinaria y la capacitación permanente se identifican como aspectos que potencian la atención a los pacientes con cáncer.

Palabras clave: enfermería; enfermería oncológica; oncología médica; manejo de la enfermidade; teoría fundamentada en los dados

Received for publication: 24.05 .16 Accepted for publication: 28.09 .16 


\section{Introduction}

The significant increase in the number of cancer diagnoses has turned cancer into the second leading cause of death in Brazil. The prominence of this disease in the health agenda has become evident based on the major investments in research and the volume of published works on this topic (Cristo \& Araújo, 2011). The efforts towards achieving an ideal professional performance when caring for cancer patients are a national concern, as evidenced by the creation of the National Oncology Care Policy by the Brazilian Ministry of Health, which includes promotion, prevention, diagnosis, treatment, rehabilitation and palliative care interventions. This policy also states that assistance in highly complex situations must be provided by high complexity oncology health care units and centers (Portaria n. ${ }^{0}$ 2.439/GM de 8 de dezembro 2005).

However, nursing interventions in cancer situations often do not follow the recommendations due to the limited number of specialists, the clinical complexity, the aggressive and extended treatments, and the structural and organizational difficulties faced by the services, among others. These aspects constitute a barrier to the training of professionals who are both interested in this area and sensitive to specific issues. Such factors contribute to increase the stress and burden of professionals caring for cancer patients (Cubero \& Giglio, 2014).

It should be noted that due to high demand, many general hospitals admit cancer patients and eventually deliver care that does not meet the specificity and complexity of these cases (Silva, Moreira, Leite, \& Erdmann, 2012). The delivery of specialized care in general hospitals impacts the quality of care, adversely affecting not only health professionals, particularly nurses, but also patients and family members.

Therefore, nursing care management is an important tool to improve care delivery by promoting integral care, with a view to achieving an individualized care delivery (Cristo \& Araújo, 2011). To this end, it uses instruments such as the proficient organization of health services, their connection with support services, and the systematization of nursing care (Soares, Resck, Terra, \& Camelo, 2015).

Thus, this study aimed to understand the meaning of the management of nursing care delivery to cancer inpatients admitted to a general hospital located in southern Brazil.

\section{Background}

Cancer is a generic term for a large group of diseases resulting from cell changes (World Health Organization, 2014). Within the current changes in the global epidemiological profile and increased life expectancy, the incidence of cancer is increasing in Brazil and in the world, and it is now one of the leading causes of death in Brazil (Ministério da Saúde, Instituto Nacional de Câncer José Alencar Gomes da Silva, 2015). Cancer is the second most fatal non-communicable disease in the world, only behind cardiovascular diseases. More than two thirds of cancer deaths occur in low-and middle-income countries. As to the type of cancer, more than half of cancer deaths are due to colorectal, liver, stomach, breast and lung cancer (World Health Organization, 2014).

The need to provide complex care to cancer patients requires a qualified care management. This entails a greater attention when systemizing nursing care, which, in turn, involves cooperation between care and management dimensions. In this sense, nurses must provide an evidence-based, specialized, quality care, taking into account their clinical expertise and the patients' values (Mesquita et al., 2015).

The delivery of nursing care to critically ill patients is complex and must be highly specialized in order to prevent complications, thus reducing disabilities and seeking recovery and quality of life (Regulamento $n^{\circ}$ 124/11 de 18 de fevereiro). In the Brazilian context, care is provided by general practitioners, nurses and technicians/nursing assistants (technical level professionals). No specialization in this area is required (COFEN. Conselho Federal de Enfermagem. Decreto 94.406/87, 2016). In contrast, in Portugal, the Order of Nurses established that the diagnostic evaluation, the constant surveillance, and the supervision of complex critical illness processes belong to the specialist professionals' skills set, given the complexity of the situation, which contributes to the qualification of care (Regulamento no 124/11 de 18 de fevereiro).

\section{Research questions}

Based on the above described context, the following questions were formulated: How is the delivery of care to cancer patients managed by nurses in inpatient units of a general hospital? How do nurses 
feel when performing this activity? Who is involved in the health/disease process?

\section{Methodology}

This is a qualitative research that used the Grounded Theory (GT) methodology. GT aims to identify, develop and relate concepts, allowing a theoretical model to emerge from the data analyzed and constantly compared, setting up an important guide for action (Strauss \& Corbin, 2008).

The study was conducted at an inpatient medical unit of a general hospital in the south of the country. Data were collected between August and October 2010, through semi-structured interviews with the following guiding question: How do you experience and assign meanings to the management of care delivery to cancer patients admitted to this inpatient unit? This question was the starting point to the interview with the participant. We would pose questions based on the participants' accounts, and look for specificities in their perceptions and on the individuals involved in the process. Data were collected by two students in the final semester of the undergraduate nursing degree under the supervision of a researcher specialized in the topic and the method. The interviews lasted on average 30 minutes and were digitally recorded and subsequently transcribed in full.

The study participants were selected based on the theoretical sampling method, i.e. the process through which the researcher, based on the answers and research hypotheses, decides where and from whom information could be obtained (Strauss \& Corbin, 2008).

Initially, all nurses working in the inpatient unit were invited to participate in the study. We selected six nurses from the medical inpatient units based on the following inclusion criteria: professionals working in direct patient care at the institution for a minimum period of 6 months; and exclusion criteria: nurses on leave and on holiday. Nurses were chosen as the starting point for the data collection process because they are in charge of managing care and overseeing the team's direct nursing care interventions towards cancer patients. Their accounts raised questions about the importance of the nursing team, demonstrating the need for conducting research with these professionals. In this way, the five nurses for the second sample group were selected based on the above-mentioned inclusion and exclusion criteria. With this group, we were able to strengthen some categories and develop more hypotheses. The most important hypothesis was: The integrated multidisciplinary team and family participation promote a qualified care delivery. Based on these findings, the third sample group was composed of a family member of each cancer inpatient, a psychologist and a nutritionist, in a total of 14 participants. Data saturation was reached when information was repeated and no new relevant data for the research were obtained.

The analysis process included the data encoding, which occurred simultaneously with data collection, and was divided into three stages: open, axial, and selective coding. Open coding was the first step for analysis, consisting of separating, examining, comparing, and conceptualizing the data obtained. In this stage, data were analyzed line by line, translating interviewees' accounts into codes and then grouping them by similarities and differences. The second stage of analysis was axial encoding, where data were regrouped into subcategories and categories. Selective coding consists in searching and developing the core category or phenomenon around which all other categories revolve (Strauss \& Corbin, 2008). In order to achieve methodological rigor and ensure data internal consistency, diagrams were developed in the analysis process to represent each interview, focusing on the key concepts and their relationships. In addition, three nurses from the first sample group validated the data and suggested minor adjustments in writing the names of the categories and subcategories. The paradigmatic model was used in this study. It establishes a relationship between the categories and the phenomenon, identifying and classifying them as context, causal conditions, intervening conditions, action/interaction strategies, and consequences (Strauss \& Corbin, 2008).

The research complied with the ethical principles of Resolution 196/96 of the National Health Council of Brazil, and the study was submitted to and approved by the Ethics Committee on Human Research of the Federal University of Santa Catarina (CEP/UFSC), under protocol number $897 / 10$. The interviews were conducted after explaining the study objectives and methodology to the participants, who signed the informed consent form (ICF) in duplicate. The participants' anonymity was ensured by using the initial letter of the word participant and a number 
corresponding to the data collection sequence (P1, $\mathrm{P} 2, \mathrm{P} 3 \ldots)$.

\section{Results}

The core category Understanding how professionals excel themselves and how important is interdisci- plinarity when comparing the management of humanistic and humanitarian nursing care recommended for cancer patients with the health professionals and family members' experiences in an inpatient unit of a general hospital emerged from the dynamic interaction between the 13 categories, divided into the five components of the paradigmatic model, as shown in Figure 1.

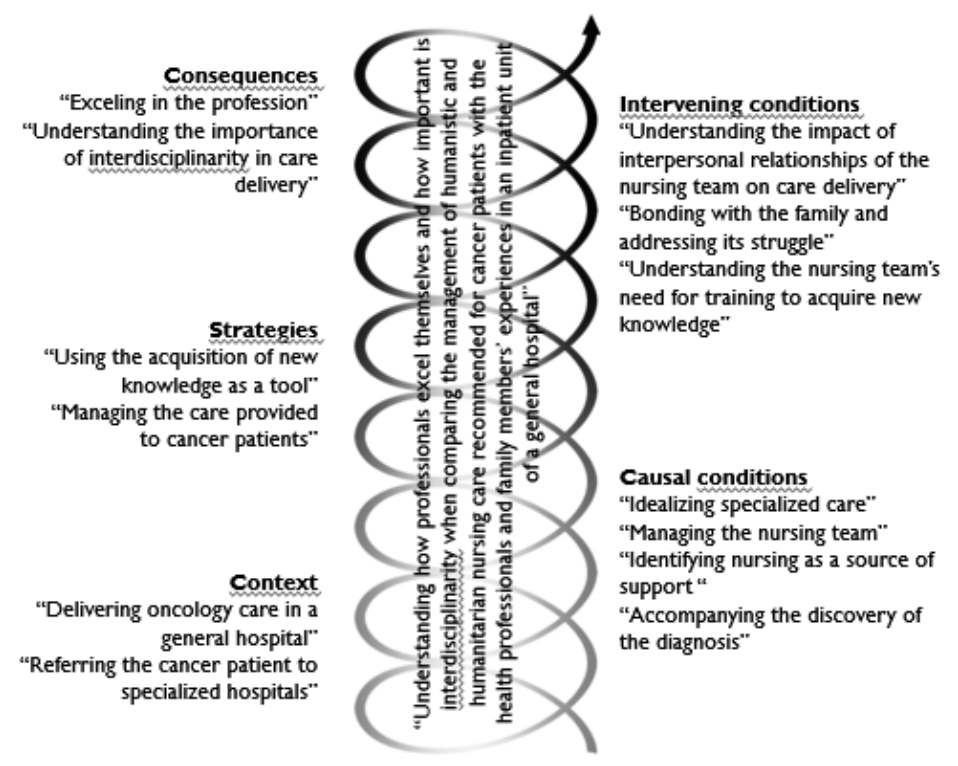

Figure 1. Diagram of the theoretical model.

\section{Context}

The category Delivering oncology care in a general hospital reveals the scenario that served as basis for the development of the core category. It indicates that the assistance to cancer patients is often included in routine care, and, for this reason, patients lack the necessary specialized assistance, as illustrated by this account:

In oncology, care is very specific. It's not only the technical aspects, but we have to be more sensitive. Everything is different ... And medications mainly used to control pain, opioids, are drugs that are still surrounded by many taboos. And professionals are afraid to use them, yes. So I think that yes, a well specialized care is needed. (P3; August, 2010)

Referring the cancer patient to specialized hospitals is the category that describes the professional commitment characterized by anxiety when faced with situations that require patient referral to other institutions, as one of the participants mentioned:
Our major difficulty is that, as it is not our area of expertise, oncology, we keep on waiting for a vacancy in another specialized institution . . . Since we don't have such a care protocol to follow, what can we do with this patient? (P3; August, 2010)

\section{Causal conditions}

The category Idealizing specialized care, i.e. characterizing the actions believed to motivate the core category, shows the importance of creating a specific care model targeted at cancer patients according to their specificities and peculiarities, since the unit does not give them this type of care, as this account shows:

Because, although he was diagnosed with cancer, he does not necessarily undergo a specific cancer treatment. He is usually admitted to gastroenterology or pulmonology units, or even the medical unit, where this diagnosis is not directly treated and addressed. No specific care 
is offered to the meet the patient's needs. (P2; August, 2010)

The nurse should present this difference between the care recommended by professionals and the care delivered at the units to the team. The category Managing the nursing team proved to be important throughout this research, by pointing out that the nurses' management tasks are, along with care delivery, essential for the proper functioning of an inpatient unit, as demonstrated by this account:

Shift change is a great time to adjust what must be adjusted, restructured. The nurse understands that we are talking about him. If he does not change, we call him aside and talk to him in private. First, we have to organize the team, so that everyone does their best. (P2; August, 2010) Identifying nursing as a source of support is the category that shows how the nursing team is sensitive and alert to cancer patients' health situation, providing support given the vulnerability caused by the disease. Reports show that professionals have become a point of reference for patients and families when they feel insecure or have any doubts, as mentioned by this participant:

Other [patients] end up seeing us as a source of support and affection. Because, when you show up in the hallway, he greets you, gives a happy smile, it's something that you see in the visit, during your work. When you stop to talk to him, then he responds in a positive way. (P3; August, 2010)

The category Accompanying the discovery of the diagnosis reveals the general care provided in the unit at the time of diagnosis and the period before that, when the patient comes to the unit to investigate the symptoms related to the clinical specialties. The waiting time causes anxiety in the patient and it is then that the nursing team pays attention to the changes that this patient will undergo, as mentioned by this participant:

We start working with them before they even know that they are cancer patients. Because they end up discovering this diagnosis here. I don't like to mislead the patient. But that doesn't matter, I only answer when he asks me a question. I also think that he needs some time to process if he is ready know the answer to that. (P5; August, 2010)

\section{Intervening conditions}

As intervening factors of the core category, which have the potential to be facilitating or hindering factors, the category Understanding the impact of interpersonal relationships of the nursing team on care delivery describes the meaning that many professionals assign to a good relationship within the team and its impact on a qualified patient care. Professionals reported that, when working together, they are more aware of the patient's needs, although the discussion of clinical cases is not a common practice. Professionals are often influenced by personal friction that prevents dialog, as can be seen here:

The problem is that sometimes the patient realizes ... We see that a patient feels more at ease working with a team, with another team he becomes kind of distrustful, less at ease. So much so that some professionals manage to gather more information from the same patient and others don't. (P11; September, 2010)

In the category Bonding with the family and addressing its struggles, the participants revealed that the bond between patients and their relatives often becomes even stronger after the diagnosis and that it has a positive impact on treatment, as can be seen in this account:

We see that a patient who feels more supported recovers more quickly, gets less depressed, has less pain, eats better, and gets out of bed more often. So I think that it helps improving their health, their immunity. (P9; September, 2010)

In what concerns this aspect that promotes the core category, nurses have the responsibility to encourage the family to participate in the health/disease process, by staying close and helping in the process of coping with the disease. Nurses should also be aware of the relatives' psychological needs, in order to reduce their emotional distress, as can be seen below:

I still need to work on this aspect in the unit with our staff because the family is not experiencing the physical pain of cancer, rather its psychological pain, which is very serious. We need to stay close to the family and encourage them to stay together in all moments. (P6; August, 2010)

In the category Understanding the nursing team's need for training to acquire new knowledge, the study participants pointed out the difficulties experienced by professionals dealing with complex cancer situations with no institutional support for continuing education. They emphasized that the occasional multidisciplinary discussions and the lack of specific training sessions, on ways to ensure 
comfort and non-pharmacological alternatives for pain management, make the caring process too exhausting for professionals, as can be seen below:

I was talking about this today. This matter is very disorganized. Each one of us provides care in the way we think is correct, but sometimes what we consider to be correct is not the best alternative ... We become emotionally distressed because the patient often does not react well to our interventions. (P2; August, 2010)

\section{Strategies}

The category Using the acquisition of new knowledge as a tool shows the idealization of strategies to overcome the issue described in the core category. Professionals recognize the constant knowledge update as a necessary factor to provide safe and qualified care to cancer patients. According to the nurses, the constant exchange of knowledge during work, the transmission of information during shift turnovers, and the study on the specialties of higher incidence in the hospital are strategic actions, as can be seen in the following account:

Some professionals are not very open to new knowledge, they are more resistant. I always try to bring information that can add to the care being provided. Even if some team members are less interested, I do it because I believe that I'm giving a contribution. (P3; August, 2010)

These strategies partly express how nurses are Managing the care provided to cancer patients. In this category, participants showed the importance of care management in the development of the team's care interventions, as illustrated in the following account:

Because we always do what we can, encouraging the staff, providing guidance, talking with the team ...., reflecting on the patient's well-being to actually manage care and do our job in the best possible way. (P4; August, 2010)

\section{Consequences}

As repercussions of the core category, professionals revealed their frustrations and achievements in relation to the effectiveness of the interventions recommended for cancer patients. In the category Exceling in the profession, it is evident that professionals who are satisfied with their profession feel more motivated, as reported by the following participant:
Despite my lack of experience with cancer patients ... I get to the hospital every day, and I still feel as if I'm going for a leisure activity, and when I get to my car, I'm always tired but I sit down and say: What a good feeling, one more day! I leave with the sense of a duty fulfilled. (P6; August, 2010)

According to the participants, the ideal care delivery sought by nurses will only be achieved in cooperation with the health care team. Nurses mentioned that the provision of specialized care to cancer patients requires professionals to adequately communicate the patient's health situation, as well to discuss the team's performance. The category Understanding the importance of interdisciplinarity in care delivery reveals the professionals' perception of the benefits of interdisciplinary interventions in the provision of care to cancer patients, as well as the difficulties arising from inefficient communication, as demonstrated in this account:

This joint action facilitates [care] a lot, because they already know that, when I ask them something, it is because I believe that it will benefit the patient ... Whether it is a physician, psychologist or nutritionist, they know that I am not saying that just because I want something, I want it because I really need it. And, if they cannot come, they justify it very well. (P4; August, 2010)

Nursing was also seen as an important axis of communication between the different health professionals, highlighting the importance of nursing management in strengthening the delivery of integral care.

\section{Discussion}

Although this study was conducted in a large hospital, one of its limitations was that the research was conducted in a single inpatient unit, not extending to other units where cancer patients are also admitted. In view of the complexity of oncology, the delivery of nursing care to these patients, and the great demand of the general hospital and the unit where the study was developed, we believe that the management of nursing care delivery to cancer patients and the relations within the context of a general hospital should be discussed.

In general health institutions, patients are admitted based on the multiplechanges of their health condition, 
which hinders care specificity. Consequently, nursing care usually does not consider all the biopsychosocial needs of each patient. The delivery of oncology care should recognize the patients and families' actual health needs so that adequate intervention strategies can be defined and implemented (Oliveira \& Firmes, 2012).

The Brazilian reality recommends that high complexity oncology care should be delivered in high complexity oncology units and centers, so as to ensure care specificity and promote care quality (Portaria $\mathrm{n}^{\circ}$ 2.439/GM de 8 de dezembro, 2005).

However, the extremely fragmented knowledge of the specialties compromises integral care, without treating the patient as a whole. With this in mind, the Brazilian Ministry of Health promotes the implementation of interventions aimed to overcome the fragmentation of health interventions through intersectoral cooperation, with a view to achieving greater effectiveness and efficiency (Portaria n. ${ }^{\circ}$ 2.439/GM de 8 de dezembro, 2005).

The professionals' concern to refer cancer patients from the general institution to a specialized hospital or clinic was evident, since they believe that the patient will benefit from better infrastructures, and better psychological and therapeutic support, taking into account the unit's equipment and technology (Silva \& Moreira, 2011). Even though general practitioners feel insecure in the process of caring for cancer patients, the perception that specific actions should be performed together with the search for knowledge is an indication that this challenge will be overcome and sustains a safe clinical practice.

With regard to health team management, the results show that communication emerges as an important organizational management tool for professional integration and bonding with the patient/family. To achieve a successful management within health institutions, nurses should be the link in the communication chain, since they are in constant contact with the rest of the team. Communication has an impact on the operational dynamics of the institution and, through it, nurses are able to raise the team's awareness about the need for improving clinical practices (Santos, Lima, Pestana, Colomé, \& Erdmann, 2016).

Although the results of this study show that members of the nursing team were often afraid to discuss the disease with the patient, the dialog with the cancer patient is necessary. This bond of trust allows patients to express their fears, encouraging them to voice their doubts, anxieties and expectations in a true relationship of help, solidarity and support to face the situations related to the onset of the disease (França, Costa, Lopes, Nóbrega, \& França, 2013).

Literature shows that a good interpersonal relationship among the professionals involved in the care process and the efficient communication between the team members are facilitating factors of the care process in critical health situations (Matos, Pires, \& Gelbcke, 2012), which is in line with the results of this study.

The participation in the process of discovering the disease is a challenge for healthcare professionals. The patient has to be prepared for the revelation of the diagnosis and prognosis, particularly in institutions that lack adequate structures. Although the revelation of the diagnosis is a medical responsibility, nurses are in a privileged position, given their close contact with the patients, to identify their actual needs to receive certain information (Amador, Gomes, Coutinho, Costa, \& Collet, 2011).

Thus, the importance of the health team throughout the disease and treatment process is demonstrated in the assurance provided to the families, making it a reference in moments of doubt and vulnerability, pointing to the need for the team to encourage nurses to include the families in the care process (Silva et al., 2012).

The professional's perception of not being able to offer adequate care stands out as a major difficulty in managing care delivery to cancer patients, and as a potential trigger of mental distress among these professionals (Fernandes \& Komessu, 2013).

Pain is often addressed through the professional's denial for not being able to suppress it with analgesics. In addition to the subjective assessment of pain and the often insufficient use of analgesics, another related issue is the bias toward the use of opioids and the health team's lack of knowledge about pain management, which is a direct effect of the professional's lack of training (Infante, 2011).

The knowledge updates suggested by the participants in this study are aimed at developing the theoretical basis that allows professionals to better adapt to the specificities of the work environment. The topic to be addressed depends on the demand, with the purpose of improving the team's daily work and care delivery. It is the nurse's responsibility to identify the needs 
and act in this process, addressing the topic proposed in order to train the team (Amador et al., 2011).

It seems clear that nursing care management in a general hospital is influenced mainly by the consequences of interdisciplinary interaction, as well as by the nurses' perception of their performance in terms of achievements and frustrations associated with the profession. Thus, interdisciplinarity leads to the delivery of integral care to critically ill patients. These interventions basically reflect the bioethical principles, namely responsibility, to be followed by health professionals. Interdisciplinarity enables the integration of knowledge from different healthrelated disciplines, fostering the relationship between the different professions. The comprehensiveness of health actions promotes the responsible intervention of the professionals involved in patient care (Pradebon, Erdmann, Leite, Lima, \& Prochnow, 2011).

\section{Conclusion}

The management of the nursing care delivery to cancer patients is strategic for the provision of patient-centered care, leading to qualified care delivery. In this context, professionals aim to provide care in the most specific way possible in the general health institution, choosing to refer the patient to a specialized institution whenever possible. We concluded that patients and families see nursing professionals as a source of support, especially in delicate times such as the diagnosis and the dying process. We also observed that the professionals feel frustrated with the provision of general care to patients in non-specialized institutions, revealing the professional's sensitivity and self-criticism towards care. We highlight the nurse's role as care manager, by raising the nursing team's awareness to the importance of specialized care, interacting with the multiprofessional team, identifying gaps in care delivery, and promoting effective solutions through a combination of knowledge from different areas. We have also identified the need for continuous training to improve care delivery, and for institutional support through investment in studies in this domain, with the purpose of finding strategies to overcome this issue.

\section{References}

Amador, D., Gomes, I., Coutinho, S., Costa, T., \& Collet, N. (2011). Nurses' conceptions about pediatric oncology care training. Texto \& Contexto Enfermagem, 20(1), 94101. doi:10.1590/S0104-07072011000100011

COFEN. Conselho Federal de Enfermagem. Decreto 94.406/87. (2016) Retrieved from http://www.cofen.gov.br/ decreto-n-9440687_4173.html

Cristo, L., \& Araújo, T. (2011). Comunicação e oncologia: Levantamento de estudos brasileiros. Brasília Médica, 48(1), 50-57.

Cubero, D., \& Giglio, A. (2014). Entendendo a síndrome de burnout na cancerologia. Revista Brasileira Medica, $71\left(\mathrm{n}^{\circ}\right.$ esp.m 2), 3-8. doi:S0034-72642014018200001

Fernandes, M., \& Komessu, J. (2013). Desafios do enfermeiro diante da dor e do sofrimento da família de pacientes fora de possibilidades terapêuticas. Revista Escola Enfermagem da USP, 47(1), 250-257. doi:10.1590/S008062342013000100032

França, J., Costa, S., Lopes, M., Nóbrega, M., \& França, I. (2013). Importância da comunicação nos cuidados paliativos em oncologia pediátrica: Enfoque na teoria humanística de enfermagem. Revista Latino-Americana de Enfermagem, 21(3), 780-786. doi:10.1590/S0104-11692013000300018

Infante, S. (2011). Iatrogenic cancer pain and its prevention. Revista Dor, 12(1), 54-57. doi:10.1590/S180600132011000100012

Matos, E., Pires, D., \& Gelbcke, F. (2012). Implicações da interdisciplinaridade na organização do trabalho da enfermagem: Estudo em equipe de cuidados paliativos. Revista Eletrônica Enfermagem, 14(2), 230-239. doi:10.5216/ree.v14i2.13237

Mesquita, M., Paes, G., Silva, M., Duarte, S., Erdmann, A., \& Leite, J. (2015). Gerência do cuidado de enfermagem ao homem com câncer. Revista de Pesquisa Cuidado é Fundamental Online, 7(3), 2949-2960.

Ministério da Saúde, Instituto Nacional de Câncer José Alencar Gomes da Silva. (2015). Estimativa 2016: Incidência de câncer no Brasil. Retrieved from http://www.inca.gov.br/ estimativa/2016/estimativa-2016-v11.pdf

Oliveira, M., \& Firmes, M. (2012). Sentimentos dos profissionais de enfermagem em relação ao paciente oncológico. REME: Revista Mineira de Enfermagem, 16(1), 91-97. doi:S1415-27622012000100013

Portaria n. ${ }^{0}$ 2.439/GM de 8 de dezembro. (2005). Retrieved from http://www1.inca.gov.br/inca/Arquivos/Legislacao/ portaria_2439.pdf

Pradebon, V., Erdmann, A., Leite, J., Lima, S., \& Prochnow, A. (2011). Complexity theory in the daily experience of the nurse manager. Acta Paulista de Enfermagem, 24(1), 1322. doi: $10.1590 / \mathrm{S} 0103-21002011000100002$ 
Regulamento $\mathrm{n}^{\mathrm{O}}$ 124/11 de 18 de Fevereiro. Diário da República $n^{\circ}$ 35/11, II Série. Ordem dos Enfermeiros. Lisboa, Portugal.

Santos, J., Lima, M., Pestana, A., Colomé, I., \& Erdmann, A. (2016). Estratégias utilizadas pelos enfermeiros para promover o trabalho em equipe em um serviço de emergência. Revista Gaúcha de Enfermagem, 37(1), e50178. doi:10.1590/1983-1447.2016.01.50178

Silva, M., \& Moreira, M. (2011). Standardization of nursing care in a palliative care oncology setting: Perceptions of nurses. Acta Paulista de Enfermagem, 24(2), 172-178. doi:10.1590/S0103-21002011000200003
Silva, M., Moreira, M., Leite, J., \& Erdmann, A. (2012). Analysis of nursing care and the participation of families in palliative care in cancer. Texto \& Contexto Enfermagem, 21(3), 658666. doi:10.1590/S0104-07072012000300022

Soares, M., Resck, Z., Terra, F., \& Camelo, S. (2015). Sistematização da assistência de enfermagem: Facilidades e desafios do enfermeiro na gerência da assistência. Escola Anna Nery, 19(1), 47-53. doi:10.5935/1414-8145.20150007

Strauss, A., \& Corbin, J. (2008). Pesquisa qualitativa: Técnicas e procedimentos para o desenvolvimento da teoria fundamentada (2 $2^{\mathrm{a}}$ ed.). Porto Alegre, Brasil: Artmed.

World Health Organization. (2014). Global status report: On noncommunicable diseases 2014. Geneva, Switzerland: Author. 
